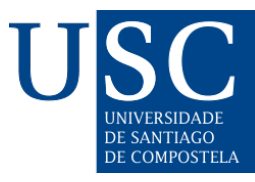

REVISTA INTERNACIONAL de

COMUNICACIÓN y DESARROLLO

Revista Internacional de Comunicación y Desarrollo (RICD), 4(15), 2021. ISSN-e: 2386-3730

https://doi.org/10.15304/ricd.4.15.8014

Artículos de Investigación

\title{
Journalists from Local Media in Sibiu (Romania) and the Challenges of Goal 11 from UN Agenda 2030
}

\author{
Minodora Sălcudean \\ "Lucian Blaga" University of Sibiu, Romania \\ minodora.salcudean@ulbsibiu.ro
}

Recibido: 15/02/2021; Aceptado: 25/05/2021

\begin{abstract}
This article addresses how journalists in the local press are interested in covering topics in the field of sustainable development, more precisely those connected with SDG11 - sustainable cities and communities. While the theoretical framework investigates recent studies on the general relationship between media and sustainable development, the applied part of this paper consists of empirical research aimed to distinguish this relationship, especially concerning SDG11 locally, in Sibiu, a city from central part of Romania. The research questions that formed the basis of the applied research were: Do local journalists know the 17 objectives of sustainable development on the UN 2030 Agenda? Regardless of whether they know the objectives or not, to what extent are local journalists interested in producing materials related to SDG 11 sustainable cities and communities? How do they understand media reporting on SDGs in general and Goal 11 in particular? How do journalists define the relationship they have with local government institutions? What about NGOs in the area of community development? How interested are the media consumers in topics related to the sustainable development of their community? For the applied part of this study, we resorted to a complementary methodological approach: on the one hand, we conducted a case study on a specific event, namely the media coverage of European Mobility Week, monitoring journalistic materials published in media outlets from Sibiu, between September 16-22, on the most relevant local news sites; on the other hand, we organized a focus group attended by eight professional journalists, full-time employees from the first two most-read local news sites: Tribuna (three people) and Turnul Sfatului (five people). The group interview comprised some pre-set questions, but we also included adjacent queries destined for clarification in-depth. The main advantage of the use and combination of the two research methods - case study and focus group - is to obtain quantitative and qualitative data relevant to journalistic practices in the local press with reference to a specific topic.

The most relevant conclusion of this research is that the way in which journalists from the local press relate to the objectives of sustainable development does not consider primarily the agenda of institutions, but the public interest and the specific needs of Sibiu dwellers. However, local newsrooms frequently inform about decisions and actions of local institutions, such as the City Hall or the County Council. Some of them are connected to UN Agenda 2030 and have budgets including for media trusts, which is why the press releases appear in local newspapers.
\end{abstract}

Keywords: Sustainability; SDG11; journalism; reporting; local; media; institutions; Public Relations; community; development.

Copyright $\odot$ Universidade de Santiago de Compostela. This is an open access article distributed under the terms of the Creative Commons Attribution-NonComercial-NoDerivatives 4.0 International (CC BY-NC-ND 4.0) License. 


\section{Summary}

1. General context. Romania's reporting to the UN 2030 Agenda for sustainable development and the interest of journalists for sustainability

2. Theoretical framework regarding media and sustainability. Some landmarks regarding the situation of Romanian journalism

3. Local press and community development: Sibiu, a European city through tradition, multiculturalism and openness

4. Case study: the local press in Sibiu and the media coverage of the events within the European Mobility Week, Sept. 16-22. 2021

5 . Focus group with journalists from the local media: the media's interest and role in topics related to sustainable development generally and SDG 11 particularly.

6. Conclusions and limitations

Acronyms

CJI -Centre for the Independent Journalism (Romania)

EJN - Earth Journalism Network

EMW - European Mobility Week

SDGs - Sustainable Development Goals

SDG 11 - Sustainable Goal 11

UN - United Nations

UNPD - United Nations Development Program

\section{GENERAL CONTEXT. ROMANIA'S REPORTING TO THE UN 2030 AGENDA FOR SUSTAINABLE DEVELOPMENT AND THE INTEREST OF JOURNALISTS FOR SUSTAINABILITY}

At the declarative level, Romania promptly ("it was the first Parliament out of 176 of the Interparliamentary Union to express its support for Agenda2030") and without reservations or conditions supported the enactment of the 17 ambitious goals proposed by the UN in 2015, for the next 15 years. Thus, the "Declaration of the Romanian Parliament on Sustainable Development Objectives", of 18th April 2016, mentions: "By virtue of its essentially representative nature and its constitutional law making, oversight and budgeting functions, the Parliament of Romania has a decisive role in ensuring national ownership of the SDGs, translating them into country-specific strategic priorities, objectives and targets, and in creating the necessary conditions for them to be met. " (http://dezvoltaredurabila.gov.ro/web/wp-content/uploads/2019/07/Declaratie_ODD.pd f p.2)

In 2017, the Romanian Government established the Department for Sustainable Development (GD no. 313/2017), which, among other roles,

"approves the proposed national set of measures for sustainable development, pursuing an integrated and multidimensional approach, as well as connecting the national strategy to the sustainable development goals set at the level of the European Union and the United Nations."(http://dezvoltaredurabila.gov.ro/web/dd-ro/). According to the official information on the department's website, in 2018, the "National Strategy for Sustainable Development of Romania 2030", the framework document that stipulates the vision and directions for implementation 
and implementation of the 2030 Agenda in Romania, was developed. Therefore, the institutional framework has been created, and it should produce visible changes in society. While official communication on this subject is limited and devoid of factual substance, mostly declarative, civil society, through dedicated NGOs (gender equality, non-discrimination, human rights, environment \& ecology, etc.) it has a favourable trend in terms of actions, projects and communication campaigns. In this sense, the Romanian PR Award competition, the largest public communication competition in Romania (https://praward.ro/despre/), reflects the growing concerns of NGOs for campaigns that include sustainable development. Following the same trend, mainstream and alternative media in Romania seem more and more interested in topics involving sustainable development. Thus, Recorder's investigative materials focused on illegal deforestation, corruption, or the environment and infested drinking water are widely known in Romania. The same stands for the Dela0's campaign on violence against women, a project carried out in cooperation with the Centre for Independent Journalism (https://cji.ro/dosarele-x-ale-media-2/); also, the journalistic investigations of the Libertatea newspaper in hospitals, while the Romanian Health system is being severely affected by corruption, poor funding, and the incompetence of some managers.

These are just a few recent examples that can illustrate good practices in the Romanian online journalism, which, implicitly, are in connection with the objectives of sustainable development. This predicates that public communication about actions, events, projects, or suchlike, regarding sustainable development in Romania, does not occur officially and explicitly, with pieces of information provided by the state institutions and addressed to the citizens. On the contrary, to a much greater extent, it occurs through civil society organizational PR approaches and press investigations that reveal the existing irregularities in different administration systems. On the one hand, the UN 2030 agenda with the 17 Sustainable Development Goals are not known as such in Romania, save from some politicians, as well as some journalists, or people directly interested or involved in such projects. On the other hand, issues such as gender equality, non-discrimination, quality education, or the precarious state of the medical system are among the most frequently debated topics in the public sphere. They are brought to public attention by journalists, often through investigative materials or awareness campaigns carried out by specific NGOs.

The interest of Romanian journalists in topics related to sustainability has become increasingly firm in recent years, especially from the perspective of investigative journalism approaches. For example, the subject of illegal deforestation has been debated in Romania for only a few years, following investigations conducted by independent journalistic sites. Among the topics most frequently addressed, at the level of the national press, are social issues - problems in the health system, access to education for children from disadvantaged communities, gender inequalities, discrimination, domestic violence; environmental issues - illegal deforestation, garbage and pollution in big cities, the situation of brown bears and the man-bear conflict, water quality; and economics: endemic poverty, wage levels, pensions, etc. Recently, in Romania, two journalists and an environmental activist were assaulted and threatened during the field documentation of the subject of illegal deforestation. Representatives of the Centre for Independent Journalism (CJI, 2021) as well as national publications, drew attention to the intimidation, danger, and pressure that journalists regularly face in an attempt to make revelations about the "forest mafia". (Neacșu et al., 2021)

We consider that addressing the issues related to the relationship between journalism and sustainability is met with a deontological dilemma: is it the responsibility of journalists to promote the UN 2030 agenda? Do they not turn into PR voices of some international, national, and local institutions/organizations, implicitly abdicating from the role of their critics? Because 
among the essential duties of journalists is not to promote and become a spokesperson for institutional projects, but to reveal irregularities, illegal slippage, shortcomings, acts of corruption, etc., information in the interest of citizens, which they could not reach on their own. In other words, we wonder to what extent it would be appropriate for independent journalism to do PR for the cause of institutions and organizations, even when it comes to sustainability projects? Is it not that freelance journalists investigate problematic situations, reveal uncomfortable truths, expose irregularities in the public or private sector an implicit way to support sustainable development?

On the other hand, documenting and producing educative journalistic materials about SDGs corresponds to the training and education function that journalism, especially the one found in public audio-visual, has. So, could projects, actions, initiatives beneficial to communities be covered by journalists? For example, if journalists receive money from the local administration to promote projects of community interest, can they still be critical of its representatives? The questions above can only be answered by experienced journalists, as the theory of media roles often draws artificial boundaries between ideal situations and compromises. Conversely, journalistic practice demonstrates that there is, in fact, a multitude of socio-political contexts with historical, cultural, or economic factors that determine a plethora of possibilities for the functioning of the press. (Hanitzsch et al., 2019)

At the national level, a concrete example of partnership between media \& journalism for sustainability and the business area consists of the series "Sustainable Romania", edited by journalist Loredana Voiculescu on the Republica.ro website. We note from one material on the sustainability of Romanian cities, an aspect notified by the expert co-opted to write the article, of interest for our study: "A major challenge is that in town halls and the media there are few specialists in sustainable lines of education in this direction." (Voiculescu, 2021).

\section{THEORETICAL FRAMEWORK REGARDING MEDIA AND SUSTAINABILITY. SOME LANDMARKS REGARDING THE SITUATION OF ROMANIAN JOURNALISM}

The concept of "sustainable development" or "sustainability" has experienced not only an increase in usage frequency in the media, but also a refinement of its meanings. In this sense, an article that analyses the frequency and semantic path of the phrase in six important publications in Germany, between 1995 and 2015, shows the doubling in usage frequency of "sustainability terminology" and a "semantic consolidation" of the concept of sustainability, after the year 2000. (Fisher et al., 2017)

The theoretical framework for our article has its basis in the UN approach regarding the close link between the media and sustainable development, at all three levels: global, national, local, and on all three interdependent levels: social, economic, and environmental, which requires holistic approaches.

In general, however, UNDP's media-related initiatives can be classified under three broad and interconnected areas of engagement (...): (i) promoting enabling environments - normative, legal and regulatory - conducive to free and professional media; (ii) leveraging the potential of media outlets to be actors for peace and development; and (iii) developing the capacities of social actors and governments to use media channels to achieve specific development goals. Taken together, 
these three areas of engagement encompass UNDP's ability and potential to work holistically with a range of actors and institutions in support of the media's role in governance, sustainable development and peace. These areas of work, therefore, help outline a framework for UNDP's overall approach to media engagement. (UNDP Report, 2019: 12)

We, therefore, consider the ethical standards derived from the human rights paradigm, on which the UN bases its vision on the role of the free press: impartiality and credibility. "Working with the media in support of development and operating in what can often be a politically sensitive environment requires a great deal of care. As the case studies show, an important reason why UNDP can play a convening role is its ability to act as an impartial facilitator and honest broker in bringing together a range of actors across divides, whether to amplify the voice of social actors, strengthen journalistic standards or cultivate enabling normative environments." (UNDP Report, 2019: 16)

In this sense, the UN experts have developed guides and textbooks for teachers who teach journalism connected to sustainability, such as Teaching journalism for sustainable development: new syllabi (Banda, 2015); also, journalists concerned with sustainability issues have access to different websites, applications or digital tools, such as those on the Journalist's Toolbox or the ones the Earth Journalism Network (EJN), to give just two examples of online resources which journalists can capitalize on.

We also, implicitly, take into consideration the concept of sustainable journalism that applies to organizations and journalistic practices themselves, defined as: "journalism that meets the information needs of the present without compromising the ability of future generations to meet their own journalistic informational needs" (Berglez, Olausson \& Ots, 2017, p. XXII). Also related to sustainable journalism is the concept of "Newsonomics", the discipline founded by media analyst Ken Doctor that looks at media organizations from the viewpoint of sustainable development (Apablaza-Campos, Codina, Pedraza-Jiménez, 2018) with the aim of reorganizing, according to the technological dynamics and consumption habits (and expectations) of users. Thus, a subsidiary question arises: are local media newsrooms sustainable organizations? As important nuclei with the role of information and training towards community sustainability, they become part of this process. Therefore, achieving Goal 11 - Make cities inclusive, safe, resilient, and sustainable involves independent local media organizations which are able to obtain income from sources that do not compromise their journalistic activity and ensure their editorial autonomy, connected to the problems of citizens, receptive to interactive communication with their readers, and attentive to the political agenda and the actions of local NGOs. From the perspective of professional journalism, correct and prompt information, in the spirit of factual truth and data, in addition to media coverage of events and political decisions relevant to taxpayers will increase people's confidence in the news and the filter role of the journalist.

This would be the ideal way in which the press works exclusively for the benefit of the community. However, it is worth mentioning that journalistic practice, especially in medium and small cities, part of a country that has gone through a communist regime for almost five decades, tends to vary depending on socio-cultural factors such as education (including political and civic), economic development and the standard of living, the degree of closure or openness to other cultures, the evolution of civil society, the availability of dignitaries to respect the independence of the press and so on.

The Romanian media, following the European model, in particular, is plural, diverse and covers all areas of interest. In 30 years of democracy in Central and South-Eastern Europe, the Romanian press has gone through an experimental period of transition, often marked by anomie, amateurism 
and lack of ethical standards (Gross, 1999; Coman, 2003), to become, in time, a professionalized field characterized by pluralism, landmarks, values and democratic models, connected to the European legislative framework and international codes of ethics (Coman, 2001, Petcu, 2020; Mureșan, 2011); currently, the Romanian media cover very different areas in terms of content (from current socio-political news to niches of interest: social, cultural, religious, sports, etc.). In terms of media consumption, national televisions are still the most popular channels. (Radu, 2021). However, it is noteworthy that, according to Data Report, with a population of 19 million inhabitants and an Internet penetration rate of 74\%, access to new technologies in communication is increasing. Despite the high consumption of audio-visual media, independent journalism newsrooms (e.g., Rise Project, Recorder.ro, Casa Jurnalistului, PressOne, G4Media, Dela0.ro, DoR, etc.) have gained more and more visibility and credibility in recent years. Using new communication technologies and exploiting the opportunities created by social networks, professional journalism has acquired an interactive dimension, created communities of interest and made its digital offer more flexible in the last two decades. (Sălcudean, 2015)

Also, an upward trend in the consumption of digital media content in Romania is recorded by podcasts (BRAT, 2020). The problems and obstacles faced by the Romanian media are periodically exposed in the Active Watch reports or in studies of the Centre for Independent Journalism, the most pressing matters including political partisanship, especially of traditional media trusts, sensationalism, the extent of fake news, the lack of transparency of official public communication and the difficult access of journalists to information (especially in the pandemic context), economic pressures which are subject to national and local newsrooms. To all this is added the phenomenon of digital mis/disinformation that professional journalists are forced to counter to strengthen their credibility. (Lupu, 2021) Two other relevant aspects that reveal the vulnerabilities in the Romanian media are related to the threats received by investigative journalists and the entry of journalists into politics. (Active Watch, 2019)

In a recent study comparing the way mining is reflected in newspapers from three different countries, the authors refer to the differences between the media systems in Finland and Germany, on the one hand, and in Spain, on the other. Borrowing the taxonomy of the three models of media systems identified, compared and analysed by Hallin and Mancini P (2004), the authors of the study state that the Spanish media system is: marked by polarization, "less professional" and strongly influenced by politics, a feature of younger democracies. "The communication industry is dominated by big multimedia corporate groups, coexisting with fast-growing independent digital newspapers." (Lyytimäki et al., 2021). Although the dominant media model in Europe is the liberal one, the mainstream media picture in Romania can be characterized in similar terms. The Romanian journalistic landscape has changed permanently after the fall of communism (1989), under the effect of globalization and the "triumph of the liberal model" (Hallin and Mancini P, 2004: 251), especially in the last two decades. Independent journalism and news sites are gaining more and more credibility as the habits of media consumption, including online media, of young people looking for practical and relevant information for themselves change as well. A significant aspect of theorizing is the differences between the national and local media, especially at an organizational level. The technological and economic challenges of the last decades, besides the evolution of citizen journalism, have put local journalists and newsrooms in a difficult situation (Nielsen, 2015), determining them to reinvent themselves and find solutions for survival.

Methodology. For the applied part of this study, we resorted to a complementary methodological approach: on the one hand, we conducted a case study on media coverage of European Mobility 
Week, an event directly connected to SDG11, monitoring published journalistic materials, between 16-22 September, on the four most relevant local news sites: Tribuna, Turnul Sfatului, Ora de Sibiu/ Hour of Sibiu, Sibiu 100\%, Sibiu today. The case study in this research can be a conclusive and objective example of how local newsrooms operate when it comes to an event on the agenda of local institutions and funded with European money. This method involves the quantitative collection of data, neutral observations and factual interpretations.

On the other hand, we organized a focus group with professional journalists, inviting for a twohour session, full-time employees (eight persons: five females, three males) from the first two most-followed media sites in Sibiu: Tribuna and Turnul Sfatului. The semi-structured interview was based on some pre-established questions, but also on an adjacent set of clarifying in-depth queries related to the research topic. In the socio-human sciences, the focus group is a qualitative method of collecting data and attitudes, through the technique of interview applied to a homogeneous group of people, in a comfortable and stimulating environment (Krueger and Casey, 2005). We resorted to an online focus group, through Google Meet, as journalists have very limited time and a busy work schedule, so online meetings provide more flexibility, allowing involved individuals to join from almost anywhere. Also, the pandemic context in Romania makes online meetings preferable. The interviewees were invited to join in the focus group five days in advance, the invitation stating the exclusive research purpose of this meeting, as well as the fact that it will be recorded.

After the online meetings, the audio-video recording was re-listened several times to get the relevant ideas for this research. The opinions gathered were selected according to the clarity of their expression and the adherence of the other participants in the dialogue to them. Some of the opinions presented here represent dominant currents of opinion in the two Sibiu newsrooms, where the journalists participating in the focus group come from. The moderator's intervention was kept within the limits of neutrality, encouraging journalists to express themselves according to their experience and vision. The interpretation of the results can be found in the conclusions section of this article.

We decided to combine the two methods to have cross-sectional results regarding the approach of the local press in Sibiu of the subjects from the SDG11 sphere.

\section{LOCAL PRESS AND COMMUNITY DEVELOPMENT: SIBIU, A EUROPEAN CITY THROUGH TRADITION, MULTICULTURALISM AND OPENNESS}

Sibiu or Hermannstadt (as its German name), is a historical, multi-ethnic, university and cultural city, located in the centre of Romania, with a population of 137026 inhabitants, according to the last census, in 2011. (http://www.recensamantromania.ro/wp-content/uploads/2012/08/TS2.pdf)

In 2007, Sibiu was designated the Cultural Capital of Europe, a notable event that subsequently generated numerous changes for the better: investments, increased visibility and countless sociocultural events that attracted tourists from Romania and abroad. Sibiu has become a landmark city on the map of Romania and Europe both from a tourist and a political point of view (the current president of Romania comes from this city, which he administered for eight years as Mayor). Although there is no recent census, in recent years, the population of the city has increased visibly, mainly due to socio-professional dynamics and migration of citizens from less developed areas of the country, especially from the south, or other countries. Increasing population density, industrial and real estate investments, economic evolution, and the rising number of cars, make the needs and 
problems of the residents new and acute, and the local administration is looking for sustainable solutions to solve them. Reflected through the lens of the national and international press (https ://sibiucity.ro/en/media/P5), Sibiu appears as one of the most sought-after tourist destinations in Europe (Dudescu, 2021; Carillet, 2021), but also as a city of privileged residence, with a high standard of living, according to the votes of its own inhabitants (Mihălțianu, 2020), as well as a city with European mentality.

In general, the local press in Romanian cities is economically vulnerable, media institutions managers with little interest in professional performance. Affected by political influences, the local press in Romania, tries to survive in a rather hostile climate whose consequences are eroding credibility, de-professionalization of journalists, or their abandonment in favour of other betterpaid professions. (Avădani, Lupu, 2016). Moreover, a quasi-widespread phenomenon in Romania is the tendency of local authorities to subordinate the press in a seemingly non-political manner, through various financing contracts; this limits the possibilities for journalists to investigate, document and publish the shortcomings of local institutions or the corruption of incumbent politicians. (Marin, 2018)

As for the media in Sibiu, it is consistently represented, especially in terms of websites. Sibiu has nine news sites, a local television, a local radio station, and three more radio stations related to central posts; also, some journalists employed in local newsrooms, corresponding to national media institutions. A relevant aspect of the local media is that newsrooms consist in a percentage of approx. 80, from graduates of higher studies in Journalism, from the "Lucian Blaga" University of Sibiu. This implies that, unlike other small and medium-sized cities in Romania, Sibiu can count on local newsrooms where journalists with studies in the media field / Communication Sciences are employed. Moreover, specifically in the university cities, the collaboration between the local press and the university journalism education is maintained mainly through the practice of the Journalism students, some of the graduates remaining to work in the local newsrooms post-study. Thus, over $80 \%$ of the journalists from the local Sibiu press are graduates of the higher education in Journalism.

During the first months of the pandemic, the dependence of journalists on the authorities increased even more, because the official information came exclusively through institutional channels. Therefore, journalists had to wait for figures and information through press releases or updates to the websites of public institutions, while the authorities recommended that citizens trust only official sources. Representatives of the Centre for Independent Journalism, backed by international media organizations drew attention to the danger of political subordination of the media by the state, given that the term official tended to become the only credible equivalent. In this context, for example, an investigative article, published in Turnul Sfatului in Sibiu (Bratu, 2020) about the inhumane conditions in which covid-19 patients are hospitalized and treated intensive care unit of Sibiu County Hospital was a media fray, taken over by all national televisions.

Regarding SDG11, the topics most frequently addressed in recent years in the local media in Sibiu are social, health-related, education and cultural events; in economic terms, those related to infrastructure, purchased means of transport, public roads, investments, park arrangements, commercial and entertainment areas; on the environment: the most common topics are: selective waste collection, recycling, problems caused by the landfill on the outskirts of the city, street cleaning, brown bears arriving in the city or in neighbouring localities. Press related to community development comes from local NGOs that organize events of interest to the community, many of them funded by the City Hall. For example, the Sibiu International Marathon, a project of 
the Community Foundation, in which thousands of people annually mobilize to run and support through donations dozens of social or environmental causes. This year, over 50 members of the academic community will run for two medical projects, one of which is the endowment with ultraperforming equipment of the neonatology department of the Public Hospital from Sibiu. Therefore, the link between non-profit organizations, academia and local institutions has become closer in recent years, especially by virtue of funding many of the projects of public institutions such as City Hall or County Council.

\section{CASE STUDY: THE LOCAL PRESS IN SIBIU AND THE MEDIA COVERAGE OF THE EVENTS WITHIN THE EUROPEAN MOBILITY WEEK, SEPT. 16-22.}

\section{1}

Initiated and promoted by the European Commission and connected to Goal 11, the European Mobility Week (EMW) annually takes place in several European cities whose local governments want to participate in this awareness and sensitization campaign to reduce traffic and pollution, encouraging the use of alternative means and outdoor movement. The most recent edition (2021) registered over 3000 cities, from 52 countries, including Romania. Of the 32 Romanian cities registered, only 7 (including Sibiu) ticked all three directions of this campaign, namely: Activities within the week, Permanent measures, Car-Free Day.

All the relevant news sites in Sibiu reported about European Mobility Week, the materials falling into the informative-utilitarian category. It is noteworthy that Sibiu City Hall has budgets allocated to the press for the media coverage of such projects. The statement of the Mayor, Ms Astrid Fodor, was taken over by three of the four local publications, being included in the communiqué posted on the Sibiu City Hall website: "Climate change and the quality of the air we breathe in the city require immediate action. In addition to the administrative measures taken by Sibiu City Hall for alternative mobility, a change in the mentality of each of us is necessary and urgent. Leave the car at home! Use a bicycle, scooter or public transport! If the distance is shorter, go on foot because Sibiu is beautiful! We protect the environment we live in by the selective collection of waste, but also by choosing alternative ways of producing electricity in our own households. All these actions must become our new normalcy. Through events such as the European Mobility Week, we encourage the people of Sibiu to take a step towards this change"

For this case study, we monitored four of the most read online publications in Sibiu, between September 16-22, identifying 15 journalistic materials (text, photo, video) related to EMW, as follows: Turnul Sfatului - 5, Sibiu 100\% - 4, Tribuna -3, Hour of Sibiu/Ora de Sibiu -2.

Following the monitoring of the press and the qualitative analysis of the articles on EMW, several conclusions can be drawn regarding the interest and involvement of journalists for such Community projects:

a. The fact that all relevant publications reported on the event shows that local media are interested in informing about local government projects and initiatives. The press releases of the City Hall could have been found in all the mentioned publications. From a thematic point of view, the information itself also had a utilitarian dimension, relevant to the city's inhabitants: Which streets are closed? What events will there be free tickets 
to? What will the weather be like on days with low traffic? What activities will children be able to take part in?

b. The local EMW campaign was joined by related events in the cultural area (partly funded by the City Hall), such as the Sibiu Guitar Meeting festival or moments of dance and street choreography by dancers from the Sibiu Ballet Theatre. This type of artistic moments is easily covered in real-time, both in social media by organizers or ordinary people, and in local publications, which, in turn, distribute them on social networks. Therefore, if the idea of a campaign takes root in the community, other actions in other areas can make it even more visible. Unusual events, with emotional potential, attract the attention of journalists and generate soft news.

c. There is a double interest in the media coverage of these projects. On the one hand of the local institutions to implement and promote, and with the help of the press, the UN 2030 agenda, on sustainable development, and, on the other hand, of the local newsrooms to benefit from additional advertising revenue.

d. The news about EMW from the four monitored local publications are very similar to those from the press releases on the Sibiu City Hall website, which shows that the journalists took over and minimally edited the information posted by the local administration, a common habit adopted in the local press.

e. Although the theme of the EMW campaign was very rich and, although quite a few events were organized under its auspices, the journalists limited themselves to the information received from the authorities. No atmosphere reports or storytelling, no interviews, and no complex articles in terms of documentation and angles of approach were published.

f. All the above conclusions lead to the idea that in the case of EMW, similarly to other events from the community and cultural agenda, organized by local public institutions, especially the City Hall and the County Council, local newsrooms rather played the role of PR agents from the local administration, by virtue of the advertising contracts concluded by the media institutions and the City Hall.

g. The eight journalists interviewed in the focus group organized for this research (and whose results are detailed below), claim about EMW that the information about the event complied with the contractual clauses, which is why the same information was published in the same form. The interviewed journalists admitted that neither they nor their readers are too interested in such events, which is why there were very few press materials outside advertising contracts.

\section{FOCUS GROUP WITH JOURNALISTS FROM THE LOCAL MEDIA: THE MEDIA'S INTEREST AND ROLE IN TOPICS RELATED TO SUSTAINABLE DEVELOPMENT GENERALLY AND SDG 11 PARTICULARLY}

Following a recorded group interview with eight journalists full-time employed in two of the most relevant media trusts in Sibiu, we gathered opinions on the interest of both them and users, for topics related to SDGs, in general, and at Goal 11 - sustainable cities and communities, in particular. The starting point in the group interview was the question about the knowledge and interest of 
journalists for the UN 2030 agenda. The eight interviewed journalists (five females and three males) do not know the UN 2030 agenda for sustainable development. Only one journalist from Turnul Sfatului vaguely mentioned that he read somewhere about objective 1 - "no poverty", however, he was unable to contextualize and corroborate information or adjacent data on the 17 objectives of sustainable development that Romania aims to implement through the "National Strategy for Sustainable Development."

A journalist from the daily Tribuna stated that, although he does not know the 17 objectives, "they are a utopia anyway", expressing his skepticism about the UN 2030 Agenda. Therefore, objective number 11 is unknown to the interviewed journalists as well.

However, the journalists admit by consensus that the issue of sustainable development of the city concerns them especially through the interest of the citizens. I noticed a strong identity and professional conscience, at the journalists from both media outlets, the Turnul Sfatului and Tribuna, because another inquiry (which led to several other adjacent questions) referred to media attitudes and relations with local institutions. The answers of journalists were different. Those from Turnul Sfatului claim that their independence also stems from the fact that their editorial office is delimited from the administrative department of the trust, the place where advertising contracts are registered and processed, including those with the local administration. Therefore, they are not aware of nor influenced by the money that comes into the trust from contracts with local institutions. Journalists from Tribuna believe that some of them have the freedom to decide on topics and angles of approach, including critical ones, regardless of advertising contracts with political parties or local public institutions. Journalists from this daily also believe that the subordination of a part of the local media to institutions is "a problem", just as there are preferential treatments from local institutions to journalists who have become "housewives of institutions". For example, they claim that communication with the City Hall is deficient, either because of the staff or the spokesperson. One of the journalists present stated that it is crucial for journalists to differentiate between the "public interest and the interest of communicators", emphasizing the idea that journalists have a role not so much to promote what the institutions want for but to sanction their illegal or unethical slippage.

On the other hand, the journalists from Tribuna (the oldest newspaper in the city that appears both print and online) say that it is the duty of the local journalist to promote public policies and support any efforts that help improve lives while maintaining its autonomy from the authorities and institutions.

Regarding sustainability issues, the interviewed journalists say that, although they do not know the UN 2030 agenda, they understand global and European trends in this direction, however, they believe that too little action is taken at a national and local level. One journalist from Turnul Sfatului said: "all the development strategies of Sibiu municipality are made following what non-reimbursable European funds can be obtained." He admits that he now makes the connection between the topics of interest of the European Commission and the actions of the local administration, topics that the local press implicitly addresses.

To a significant extent, the discussion revealed not only the skepticism towards the authorities but also the belief and the suspicion that politicians have personal rather than community interests.

Asked which topics in the field of sustainability are the most searched, read, distributed, and commented by users, the interviewees exemplified: road traffic, closed streets, zonal rehabilitation, the city's landfill, and free time. Although, the most viewed materials in the local press are the negative, dramatic ones (crimes, rapes, violence, family dramas), or those that refer to controversial 
topics and generate interaction on social media, materials with helpful, proximity information are also highly followed by users.

The interviewed journalists consider that their activity stands in the field of journalism (including the critical and investigative one, not only in the strictly informative one) rather than institutional PR, due to the publication of writing pieces that reveal administrative minuses and errors, intended to put pressure on the decision-makers: civil servants, hospital directors, institutional representatives.

\section{CONCLUSIONS AND LIMITATIONS}

The relevant aspect that emerges from the present research refers to the detached and skeptical position adopted by the interviewed journalists towards the steps taken by the UN and the Romanian government regarding the 17 SDGs. From what they said, the topics related to the sustainable development of the city are important, but their journalistic approach considers their role of information, but also critical of the authorities. The interviewed journalists also invoked the public interest as an essential stake of their activity. For example, one of the journalists present at the focus group considers that even if the reduction of traffic and the use of alternative green mobility methods are related to the achievement of Goal 11, if the city residents request additional parking places, then this will be the interest pursued by journalists, prompting them to subject the responsible authorities to critics.

Monitoring and analysis of the EMW shows that local public institutions, especially the City Hall and the County Council, followed by many other cultural or educational institutions, oftentimes pay the local publications in exchange for promotion. However, as the interviewees state, this does not influence possible journalistic investigations.

There is a discrepancy between the trends revealed by reports (Avădani, Lupu, 2016) or press investigations (Marin, 2018), regarding the subordination of the local press in Romania to the authorities and the editorial independence the interviewed journalists consider having. One of those present mentioned "self-censorship" as an attitude present in some ("less experienced") journalists who avoid being critical, talking about irregularities, or touching on topics with potential conflict.

The main limitation of this research is that it only covers the local press in Sibiu. An extension to the national level of very different socio-demographic and cultural areas and cities in Romania could compose an eloquent picture on the interest of journalists for topics in the field of sustainability. Also, even for the local press in Sibiu, an extended monitoring period is required in order to identify and analyse, during a year or, comparatively, between one year and another, the correlation between the sustainable development agenda of local institutions and factors influencing media coverage.

This paper is one of the first scientific articles in Romania that connects the issue of sustainability with journalism and can be a starting point for conducting much more extensive and in-depth research. 


\section{REFERENCIAS BIBLIOGRÁFICAS}

Apablaza-Campos, A., Codina, L.; Pedraza-Jiménez, R. (2018). Newsonomics in the Interactive Era: Dimensions of Sustainability in the News Media. In Pérez-Montoro, M (ed.). Interaction in Digital News Media.From Principles to Practice (pp. 115-146). Springer.

Avădani, I., Lupu, C. 2016. State of the media sector in Romania in 2014 - 2015 - Vulnerabilities and possible solutions, IJC report, project financed by EEA grants 2009 - 2014.

Banda, F. (ed.). (2015). Teaching journalism for sustainable development: new syllabi, UNESCO Series on Journalism Education.

Active Watch, FreeEx - Freedom of the Press in Romania 2018/2019. https://www.activewatch.ro/ro/freee x/publicatii/lansarea-raportul-freeex-2018-2019-libertatea-presei-in-romania.

Berglez, P., Olausson, U. \& Ots, M. (2017). What Is Sustainable Journalism? Integrating the environmental, social, and economic challenges of journalism. Peter Lang. https://www.peterlang.com/document/10 $\underline{55603 .}$.

Voiculescu L. (ed.) (2021, August 21). Sustainable Romania. "I'm waiting for the moment when the school principal comes by bike to school and not by the car he parks in the school yard." How can cities become more sustainable spaces. Republica. https://republica-ro.translate.goog/romania-sustenabila-zastept-momentul-in-care-direct orul-de-scoala-vine-cu-bicicleta-la-scoala-si-nu-cu?_x_tr_sl=ro\&_x_tr_tl=en\&_x_tr_hl=en

BRAT (2020). The podcast in Romania. Romanian Transmedia Audit Office. http://www.brat-online.ro/stu diu-podcast\#Descarca\%20raport.

Carillet, J-B. (2021, January 2). Travel: the 21 destinations to (re) discover in 2021. Le Figaro, https://www .lefigaro.fr/voyages/guides/voyage-les-21-destinations-a-re-decouvrir-en-2021-20210102.

Coman, M. (2001). The media landscape in Romania. SEER: Journal for Labour and Social Affairs in Eastern Europe, 4(1), 173-186. http://www.jstor.org/stable/43292149

Coman, M. (2003). Mass media in post-communist Romania. Polirom.

Data Reportal (2021). Digital 2021: Romania. https://datareportal.com/reports/digital-2021-romania

Dudescu, D. (2021, February 10). Sibiu, the 5th place in the top of tourist destinations in Europe, in 2021. It surpassed Paris, but also Vienna, ranked only on the 18th place! Libertatea. https://www.libertatea.ro /stiri/sibiul-ocupa-locul-5-in-topul-celor-mai-bune-destinatii-turistice-din-europa-3411025

Fischer, D., Haucke, F. \& Sundermann, A. (2017). What Does the Media Mean by' Sustainability 'or' Sustainable Development '? an Empirical Analysis of Sustainability Terminology in German Newspapers Over Two Decades. Sustainable Development, 25(6), 610-624. https://doi.org/10.1002/sd.1681

Gross, P. (1999). Colossus with feet of clay: aspects of Romanian post-communist media. Polirom.

Hallin, D.C \& Mancini, P. (2004). Comparing media systems: three models of media and politics. Cambridge University Press.

Hanitzsch, T., Hanusch, F., Ramaprasad, J. \& Arnold S. (eds.). (2019). Worlds of Journalism. Journalistic Cultures Around the Globe. Columbia University Press.

Lupu, C. (2021). Journalism in 2021, The state of the media in Romania. https://cji.ro/jurnalismul-in-2021 -raport/

Lyytimäki, J., Benighaus, L., Gómez, J., Benighaus, C., Kauppi, S., Kotilainen, J. M., Mononen, T. \& del Rio, V. (2021). Mining in the Newspapers: Local and Regional Media Representations of Mineral Exploration and Mining in Finland, Germany, and Spain. Mining, Metallurgy \& Explorationm, 38, 1831-1843. https: //doi.org/10.1007/s42461-021-00453-4

Krueger, R.A. \& Casey, M.A. (2005). Focus Group Method: practical guide for applied research. Polirom. 
Marin, I. (2018). Local press, bought with public money: millions of euros per ode, arranged shows and congratulations. Recorder.ro. https://recorder.ro/presa-locala-cumparata-cu-bani-publici-milioane-d e-euro-pe-ode-emisiuni-aranjate-si-felicitari/

Mihălțianu, A. (2020). The best cities in Romania. PressOne. https://pressone.ro/cele-mai-bune-orase-dinromania

Mureșan, R. (2011). Etică și deontologie în comunicarea publică/ Ethics and deontology in public communication. Ed. Universității "L. Blaga".

Neacșu, B., Bujdei, T., Dudescu, D., Luțac, R. \& Lăutaru, A. (2021, September 17). An environmental activist and two journalists, severely beaten in Suceava County, when they were filming a material about illegal deforestation. Libertatea. https://www.libertatea.ro/stiri/un-activist-de-mediu-si-doi-jurnalisti-batuti-crunt-in-jud etul-suceava-in-timp-ce-filmau-un-material-despre-taierile-ilegale-de-paduri-3739384

Nielsen, R. K. (ed.). (2015). Local Journalism: The Decline of Newspapers and the Rise of Digital Media. IB Tauris \& Co.Ltd in association with The Reuters Institute for Study Journalism, University of Oxford.

Petcu, M., (coord.) (2020). Romanian media after 30 years. Tritonic.

Radu, R., (2021). Digital News Report - Romania. Reuter Institute. https://reutersinstitute.politics.ox.ac.uk /digital-news-report/2021/romania

Sălcudean, M. (2015). New media, Social Media and the Current journalism. Tritonic Publishing House.

UNPD report (2019). UNDP's Engagement with the Media for Governance, Sustainable Development and Peace. https://www.undp.org/publications/undps-engagement-media-governance-sustainable-deve lopment-and-peace

NOTAS

Minodora Sălcudean is a PhD in Philology and a PhD Lector in the Department of Journalism, Public Relations, Sociology and Psychology at "Lucien Blaga", University of Sibiu. Her areas of work include mass media, digital journalism, new media and social media.

Contacto: minodora.salcudean@ulbsibiu.ro 